\title{
Mnemoniklər və yaddaş üçün digər koqnitiv vasitələr tibbi təhsildə və gündəlik həkim praktikasında
}

\author{
Sahil Mirzəyev ${ }^{1}$ \\ ${ }^{1}$ Medi Club Hospital
}

Zəmin. Odəbiyyata baxış keçirilərək bəzi xəstəliklərin diaqnostikasına yardım üçün Azərbaycan dilində köməkçi yaddaş vasitələrinin ("mnemonik") istifadəsinin mümkünlüyü nəzərdən keçirildi.

Material və Metodlar. Bizim tərəfimizdən aidiyyəti olan kliniki təlimatlara, orijinal məqalələrə, monoqrafiya və rəhbərliklərə baxış keçirilmişdir. Đsasən son 10 ildə dərc olunmuş materiallara diqqət verilmişdir.

Məqsəd: Qəfil ürək dayanmasının (asistoliya və nəbzsiz elektrik aktivliyi) geri dönə bilən səbəbləri və aurasız epizodik miqren timsalında patoloji vəziyyətlərin diaqnostikası ilə bağlı yaddaşa köməkçi vasitələrin ("mnemonik" və digər koqnitiv yardımçı vasitələr) təklif edilməsi

Nəticə: Cəld diaqnostikaya kömək məqsədilə Azərbaycan qədim mifologiyasına əsasən yaradılışın 4 ünsürü (su, od, yel və torpaq) qəfil ürək dayanmasının geri dönə bilən səbəblərinin, "həssas PUMA" mnemoniki isə aurasız epizodik miqrenin diaqnostik meyarlarının yadda saxlanması üçün istifad edilə bilər

Açar sözlor: mnemonik, koqnitiv vasitələr, yaddaş

Giriş. Ümumilikdə tibbi təhsil mürəkkəb və vacib informasiyanın bolluğu, eləcə də daim bu informasiya yükünün artması ilə xarakterizə edilir. Gündəlik həkim praktikasında dəqiq diaqnozun təyin edilməsi üçün müfəssəl differensial diaqnostikanın aparılması isə kliniki təbabətin vacib bir hissəsidir. Differensial diaqnozun aparılması üçün təkcə kliniki təcrübə bəs etmir, həmçinin, ən azından verimiş kliniki hal üçün çoxlu sayda olan hansı xəstəlikləri nəzərdən keçirmək lazım olduğunu bilmək də lazımdır. Bir sira rəhbər tibbi kitablarda hər bir xəstəlik üçün geniş differensial diaqnostika verilir. Lakin real təcrübədə onların fərqləri bir yana qalsın, hətta adlarını yadda saxlamaq belə asan deyil. "Mnemonik"-lər və digər koqnitiv yardımçı üsullar məhz bu çətinliklərin öhdəsindən gəlməyə imkan verərək mürəkkəb, lakin vacib məlumatları yadda saxlamağa kömək edir $(1,2)$. Buna görə də Qərb akademik tibbi ədəbiyyatında da belə "mnemonik"-lərə çox rast gəlinir. Qeyd edək ki, "mnemonik" sözü qədim yunan mifologiyasına əsasən yaddaş ilahəsi olan "Mnemozine" adından götürülmüşdür. Biz bu məqalədə tibbi təhsildə və təcrübədə vacib hesab etdiyimiz iki kliniki problemin diaqnostikası məsələləri ilə bağlı öz fikirlərimizi tədqim edirik və güman edirik ki, yadda saxlamaq üçün oxşar vasitələrin istifadəsi həm tibbi təhsil, həm də gündəlik praktika nöqteyinəzərindən faydalı ola bilər.

\section{Asistoliya və nəbzsiz elektrik fəallığının geri dönə bilən səbəbləri}

"H"-lər və " $T$ "-lər ürək fəaliyyətinin qəfil dayanmasının (o cümlədən, asistoliya və nəbzsiz elektrik fəallığı) geri dönə bilən səbəblərini yadda saxlamağa kömək üçün istifadə edilən bir "mnemonik"-dir (3). Bu səbəblər çoxdur, mürəkkəbdir və bir qayda olaraq ingilis dilində "H" və ya "T" hərfi ilə başlayan sözlərə aid edilə bilər. Buraya Hipovolemiya (Hypovolemia), Hipoksiya (Hypoxia), asidoz (Hydrogen ion excess

- acidosis), Hipoqlisemiya (Hypoglycemia), Hipokalemiya (Hypokalemia), Hiperkalemiya (Hyperkalemi), Hipotermiya (Hypothermia), Gorginlik pnevmotoraksı (Tension pneumothorax), Ürək tamponadası (Tamponade Cardiac), Toksinlər (Toxins), Tromboz-ağciyər emboliyası (Thrombosis - pulmonary embolus) və Tromboz - miokard infarkt1 (Thrombosis myocardial infarction) daxildir (4). Olbəttə, ingilis dilindo bu terminləri yadda saxlamaq ola bilsin ki, 
asandır. Lakin Azərbaycan dilində bu heç də elə deyil. Biz asistoliyanın və nəbzsiz elektrik fəallığının ən çox rast gəlinən səbəblərini ifadə edən bu " $H$ " və "T"-ləri yadda saxlamaq üçün dilimizə və mentalitetimizə daha uyğun bir üsulu təklif edirik. Məlum olduğu kimi, Novruz bayramından öncə qədim mifologiyaya əsaslanmış dörd yaradılış ünsürü ilə bağlı çərşənbələr qeyd olunur. Bunlar su, od, yel və torpaq çərşənbələridir. Məhz bunu nəzərdə tutaraq həyata təhlükə yaratmış qəfil ürək dayanmasının səbəblərini asanlıqla yadda saxlamaq olar. Ardicıllıq mütləq qaydada vacib olmadan bu səbəblər belədir: $\mathrm{Su}$ (Hipovolemiya, hidrogen ionlar1-asidoz), Od (hipotermiya), Yel (hipoksiya), Torpaq. Torpaq anlayşına həm ürəyin elektirik fəaliyyətində vacib element olan kaliumun azlığı və çoxluğu, eləcə də hipoqlisemiya, həmçinin, ingilis dilində " $\mathrm{T}$ " qrupuna aid edilən səbəblər daxil oluna bilər. Beləliklə "torpaq" və ya "T" qrupuna daxil edilə bilən səbəblər ürək və ağciyərin travması-mexaniki s1xılmas1 (gərginlik pnevmotoraks1, ürək tamponadas1) və trombozu (ağciyər emboliyası, miokard infarktı), həmçinin, toksinlər daxildir. Ürək və ağciyər reanimasiyası üzrə mötəbər rəsmi kliniki təlimatlarda $(4,5)$ bu problemlərin diaqnostikası və müalicəsi müfəssəl təsvir edilir. Praktiki kliniki təcrübədə bu "H"-lər və "T"-ləri yerində təyin etməyi asanlaşdırmaq üçün müxtəlif üsullar təklif edilir. Bunlara misal kimi Praqa şəhəri Motol Universitet xəstəxanasının əməkdaşlarının ümumi "ABC" yanaşmasını (6) və Littmanın EKQ-yə əsaslanan yanaşmasını (7) misal gətirmək olar.

\section{Aurasiz epizodik miqren}

Başağrıları ümumi tibbi praktikada on çox rast gəlinən şikayətlərdən biridir. Beynəlxalq Başağrısı Comiyyətinin Başağrısı Pozğunluqlarının Beynəlxalq Təsnifatına əsasən bütün başağrıları birincili və ikincili olmaqla iki böyük qrupa bölünür. $\mathrm{Bu}$ tənnifatda hər bir növ başağrısının dəqiq diaqnostik meyarları verilmişdir. Belə ki, ən çox rast gəlinən başağrısı növü olan aurasız epizodik miqrenin meyarları aşağıdakı kimidir:

- A - aşağıda qeyd olunan B-C-D kateqoriyalarına cavab verən 5 və daha çox başağrısı hücumu
- $\quad$ B - ağrı müalicə olunduqda və ya natamam müalicə

olunduqda 4-72 saat çəkir

- $\quad \mathrm{C}$ - ağrının bu 4 xüsusiyyətdən ən azı 2-si var: şiddətli

nəbzşəkillidir, birtərəflidir, mötədil ya

ağrılıdır, gündəlik fiziki fəaliyyət qabiliyyəti bu ağrıları pisləşdirir və ya bu ağrılar gündəlik fiziki fəaliyyətinin qarşısını alır

- D - bu ikisindən ən azı biri var:

1. Ürəkbulanma və/və ya qusma,

2. Fotofobiya və fonobiya

E - Digər İCHD-3 diaqnozuna bundan çox uyğun gəlmir (8).

Lakin belə dəqiq meyarlara baxmayaraq həm nisbətən daha uzaq illərdə, həm də son zamanlarda hələ də dünyada miqrenin diaqnostikası ilə bağlı səhvlərə yol verilir $(9,10,11,12,13,14)$.

Ona görə də tibbi ədəbiyyatda miqren diaqnozu təyinini asanlaşdırmaq üçün müxtəlif yardımçı vasitələr təklif olunmuşdur. Bunlara misal kimi ingilis dilində "POUND" (Pulsatile qualitynəbzşəkilli, duration 4-72 hOurs - 4-72 saat çəkən, Unilateral location $\quad-\quad$ birtərəfli lokalizasiya, Nausea/vomiting-

ürəkbulanma/qusma, Disabling intensity - əmək qabiliyyətini pozan ) mnemoniki (15) və ya "Migraine İD" (16) ilə ifadə edilən meyarları göstərmək olar. Öz növbəmizdə biz yerli həkimlərimizin, xüsusilə ilkin səhiyyə xidmətində çalışanların aurasız epizodik miqrenə ilkin diaqnoz təyin edilməsini asanlaşdırmaq məqsədilə Beynəlxalq Başağrısı Cəmiyyətinin diaqnostik meyarlarını nəzərə almaqla "həssas PUMA" mnemonikini təklif edirik. Belə ki, bu meyarlara əsasən aurasız epizodik miqren başağrısının aşağıdakı xüsusiyyətlərdən ən azı ikisi istənilən kombinasiyada olmalıdır:

- Pulsasiya edən

- Unilateral

- Mötədil və ya möhkəm dərəcəli ağr1

- Akttivliyin (fiziki və/və ya zehni) enməsi 
Eyni zamanda, ağrı ilə yanaşı "həssaslıq" simptomlarından ən azı 1-i olmalıdır:

- Ürəkbulanma/qusma ("mədə həssaslığı")

- Fotofobiya ("işı̆ga qarşı həssaslıq") və Fonofobiya ("səsə qarşı həssaslıq")

Belə epizodlar on azı 4-72 saat davam edir. Simptomatik miqren (ikincili başağrısı) ehtimalına görə anamnezdə ən azı beş belə hücum olmalıdır. Lakin Amerika məktəbi ən azı altı ay müddətinə anamnezin olmasını dəstəkləyir (17).

\section{Noticələr}

Mürəkkəb, lakin vacib məlumatların unudulması həm tibbi təhsil, həm də kliniki təcrübədə çətinliklər yarada bilir. Buna görə də yadda saxlamanı yaxşılaşdırmaq üçün köməkçi koqnitiv vasitələrin istifadəsi təqdir olunur. Misal olaraq, cəld diaqnostikaya kömək məqsədilə Azərbaycan qədim mifologiyasına əsasən yaradılışın 4 ünsürü (su, od, yel və torpaq) qəfil ürək dayanmasının geri dönə bilən səbəblərinin, "həssas PUMA" mnemonikinin isə aurası epizodik miqrenin diaqnostik meyarlarının yadda saxlanması üçün istifadə edilə bilər.

Maliyyə Mənbəyi: Məqalənin hazırlanmasında heç bir kənar maliyyə mənbəyindən istifadə edilməyib.

Maraqların toqquşması: Qeyd edilməyib.

\section{ӘDӘВIYYAT:}

1. Adam L. Putnam Mnemonics in Education: Current Research and Application Translational Issues in Psychological Science 2015, Vol. 1, No. 2, $\begin{array}{lllll}130 & -139 & \text { (C) } 2015 \text { American Psychological }\end{array}$ Association 2015 https://pdfs.semanticscholar.org/8212/c386502bbb57f ac01e6676e39e1717b68edf.pdf

2. A.S. Nene, V.S. Landge, Use of mnemonics for effective teaching. IGC 2009, Guntur, INDIA https://gndec.ac.in/ igs/ldh/conf/2009/articles/T12_0 1.pdf

3. ACLS certitification institute: Sudden Cardiac
Arrest and the H's and T's

https://acls.com/free-resources/knowledge-base/peaasystole/reversible-causes-of-cardiac-arrest-hs-and-ts 4. American Heart Association Guidelines for CPR and Emergency Cardiovascular Care: part 10. Special circumstances of resuscitation (updated november

2018)

https://eccguidelines.heart.org/index.php/circulation/c pr-ecc-guidelines-2/part-10-special-circumstances-ofresuscitation/

5. European Resuscitation Council Guidelines for Resuscitation 2015: Section 4. Cardiac arrest in special circumstances

https://ercguidelines.elsevierresource.com/europeanresuscitation-council-guidelines-resuscitation-2015section-4-cardiac-arrest-special\#Introduction

6. Reversible causes of cardiac arrest 4 "Ts" and 4 "Hs" can be easily diagnosed and remembered following general $\mathrm{ABC}$ rule, Motol University Hospital approach by Miroslav Durila https://www.resuscitationjournal.com/article/S03009572(18)30123-0/fulltext)

7. Littman et al. A Simplified and Structured Teaching Tool for the Evaluation and Management of Pulseless Electrical Activity

https://www.ncbi.nlm.nih.gov/pmc/articles/PMC5586 $830 /$

8. İHS Classification İCHD-3

https://www.ichd-3.org/1-migraine/1-1-migrainewithout-aura/

9. Lipton RB, Stewart WF, Celentano DD, Reed ML. "Undiagnosed migraine headaches. A comparison of symptom-based and reported physician diagnosis." Arch Intern Med 1992;152(6):1273-8.

10. Diamond ML. The role of concomitant headache types and non-headache co-morbidities in the underdiagnosis of migraine. Neurology 2002;58 ((9 Suppl 6)):S3-9.

11. Lipton RB, Cady RK, Stewart WF, Wilks K, Hall C. Diagnostic lessons

from the spectrum study. Neurology 2002;58 (9 Suppl 6):S27-31.

12. Tepper SJ, Dahlof CG, Dowson A, Newman L, Mansbach H, Jones $\mathrm{M}$, et al. Prevalence and diagnosis of migraine in patients consulting their physician with a complaint of headache: data from the Landmark Study. Headache 2004;44(9):856-64.

13. Jasem Y Al-Hashel et al. Migraine misdiagnosis as a sinusitis, a delay that can last for many years

https://thejournalofheadacheandpain.biomedcentral.co 
m/articles/10.1186/1129-2377-14-97

14. Michele Viana et al. When cervical pain is actually migraine: An observational study in 207 patients

http://journals.sagepub.com/doi/abs/10.1177/0333102 416683917? journalCode=cepa

15. Ken Niere, The presence of four simple history features can diagnose migraine accurately. Australian Journal of Physiotherapy Volume 52, Issue 4, 2006, Page 304.

https://www.sciencedirect.com/science/article/pii/S00 04951406700137

16. A self-administered screener for migraine in primary care: The ID Migraine validation study. Lipton RB et al, https://www.ncbi.nlm.nih.gov/pubmed/12913201

17. Stewart J Tepper, Deborah E. Tepper; The Cleveland Clinic Manual of Headache Therapy, Second edition (c) Springer International Publishing Switzerland 2014, 346 pages, page 7 (17). 